\title{
MOLDOVAN AGRI-FOOD SECTOR DILEMMA: EAST OR WEST?
}

\author{
Alexandru Stratan ${ }^{1}$
}

\section{Summary}

During the period 2010-2013, Republic of Moldova launched a number of initiatives to develop the trade policy in order to ensure a more facilitating legal framework for the implementation of economic and trade relations with the key external partners. An agreement on the creation of a free trade area in the CIS was signed in this period. Similarly, Republic of Moldova started negotiating the Association Agreement with the European Union, which was signed in June this year and is part of the Deep and Comprehensive Free Trade Agreement (DCFTA).

This article aims to assess the main effects of signing the Association Agreement for the Moldovan agricultural sector, while examining its reaction, if Moldova would have opted for integration within the Customs Union - Russian Federation, Belarus, and Kazakhstan.

Key words: free trade agreement, export, import, agri-food trade, customs union.

JEL: $F 13, F 15, Q 17$

\section{Introduction}

In the recent years the agricultural sector in the Republic of Moldova has become a real concern for the public authorities responsible for policy development and this sector monitoring as well as for the entrepreneurs and population engaged in this sector. The negotiation, initialling and finally signing the Association Agreement has increased the concerns for this sector, particularly the way in which it will meet the challenges of symmetric liberalization of foreign trade with European Union countries and Turkey.

The significance of these measures is more important than trade relations facilitation, which aim at speeding up the structural reforms and overcoming the transition stage of the national economy. At the same time, the Association Agreement is as important for the national economy, as much responsibility is required on behalf of the national authorities and the entire civil society for its proper implementation. Along with the intensification of the liberalization process, many sectors of the economy will face a number of challenges to increase the competitiveness and ensure resistance to foreign competition.

1 Alexandru Stratan, Ph.D., Director, National Institute for Economic Research, Ion Creanga Street no. 45, 2064 Chisinau, Republic of Moldova, Phone: +373 69105 921, E-mail: alex_stratan@yahoo.com

EP 2014 (61) 3 (615-632) 
One of the most threatened sectors, which was granted special importance in the negotiations is agriculture, which continues to play an important role in the national economy.

\section{Problem awareness stage}

Agricultural market distortions remain a major focus of contention in world trade negotiations. Estimates of the effects of liberalising current agricultural trade restrictions indicate an approximately $\$ 385$ billion increase in global welfare, with the disproportionate share of the benefit being enjoyed by developing countries (Lambert, McKoy, 2009).

Agricultural protection continues to be the most contentious issue in global trade negotiations (Aksoy, Beghin, 2005). The proliferation of regional trade agreements in recent years has intensified the debate on the desirability of these agreements in themselves and their coexistence with multilateral free trade under the WTO (Sarker, Jayasinghe, 2007). World Trade Organization as a multilateral institution has delivered significant positive effects on members' agricultural trade despite its sensitive nature and the reluctance of members to undertake serious reform (Grant, Boys, 2012).

Given the subject of analysis of this study, it is important to understand the distinction between a Free Trade Agreement (FTA) and Customs Union (CU).

The Free Trade Agreement is a preferential trade agreement representing one of the early forms of economic integration. It may involve two or more partners who are committed to eliminate tariff and mostly, those non-tariff barriers in the mutual trade, whilst retaining its autonomy in the development of the customs tariff in the relations with third countries/ non-members (WTO Glossary), as well as promoting other trade policy issues, including participation in other formations of integration.

The Customs Union implies a higher level of integration compared to FTA. Besides the maximal elimination of tariff and non-tariff barriers to trade, the participants to the agreement that usually are geographically adjacent countries, shall adopt a common customs tariff, reaching a consensus on the degree of protection of all sectors. Therefore, the negotiation and implementation of a CU involves increased efforts in terms of time, financial resources and political concessions. By adhering to $\mathrm{CU}$, a state loses a large part of its autonomy to develop its trade policy (Chauffour, Maur, 2011).

Since the very beginning of the integration, agriculture in the European Union has been one of the most important sectors (Antevski et al., 2012).

The Republic of Moldova was included in the EU list of countries benefiting from preferences since the mid-90s, and since 2008, it benefits from autonomous trade preferences. However, the opportunities offered by this system are not fully exploited to the existing potential and the rates offered for a large part of agri-food products remain unrealized, except for some tariff headings, such as: corn, wheat, barley, wines. Moreover, some products such as those of animal origin cannot be exported to this market (Chistruga et al., 2010). 


\section{Data sources and methodology}

The objective of this study is to assess the main effects of signing the Association Agreement over the Moldovan agricultural sector, while examining its reaction, if the Republic of Moldova would have opted for integration into the Customs Union (Russian Federation, Belarus and Kazakhstan). During the investigations, the following study methods were used: statistical method, which involved researching a larger number of observations, analysis of growth rates of the economic indicators; theoretical synthesis, formulation of judgments. The information was gathered from sources of the World Bank, World Trade Organization UNCTAD, WITS and National Bureau of Statistics of the Republic of Moldova.

\section{Results with Discussion}

The agri-food sector traditionally plays an important role in negotiating the preferential trade agreements. This can be explained by the food security concerns of the public authorities of the country, welfare of the rural population, and in particular, in developed countries, the impact of imports of certain agri-food products could have on consumer safety. Moldovan agricultural production and export are specialized mostly in raw material and semi processed agri-food products (Stratan et al., 2012).

In the Republic of Moldova, the situation is quite challenging. Compared to other countries in the region, the contribution of agricultural sector to GDP growth is significant. According to the National Bureau of Statistics, in 20112, the share of agricultural sector (added value) in GDP exceeded the level of $12 \%$ of GDP, and food and beverages industry - constituted about $4.5 \%$ of GDP and more than a quarter of the added value created by the industry. The value added in industry was lower than in the agricultural sector, about $11.4 \%$ of GDP.

Graph 1. Share of agriculture in GDP and added value created in the sector per capita (in 2011)

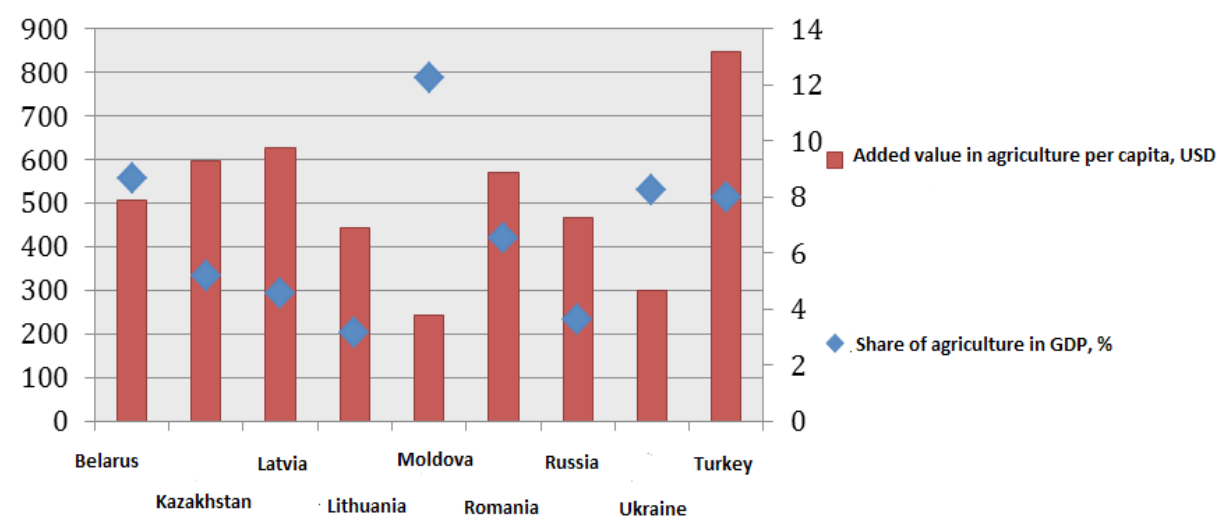

Source: According to UNCTAD data, 2012.

2 The last year for which annual data regarding GDP resources is available and the agricultural sector was not affected by natural disasters was taken into account.

EP 2014 (61) 3 (615-632) 
The contribution of agriculture to GDP growth in the Republic of Moldova is significant, although decreasing in recent years. Similarly, as indicated also by the data in Graph 1, despite the high share in GDP, compared to the Central and Eastern Europe countries, the added value created in the sector reported per capita in the Republic of Moldova is much lower.

Given the still high share of agriculture in GDP, in the Republic of Moldova a moderate correlation, positive correlation between the growth of added value in agriculture and GDP growth is observed (Graph 2). The correlation coefficient between these two variables was 0.57 in 2007-2012.

Similarly, agriculture represents an important source of livelihood of the rural population. According to 2012 data, about $18.8 \%$ of revenue comes from self-employment, $20.8 \%$ from remittances, $22.5 \%$ - social benefits (pensions, child benefits, compensation and social aid) and about $28.6 \%$ from employment. In this context, it should be noted that agriculture employs $48 \%$ of the active population in rural areas, or more than a quarter of the working population at the national level $(26.4 \%)$.

At the same time, the agricultural sector in the Republic of Moldova faces a number of constraints. In recent years, it has experienced a noticeable degradation and its structural weaknesses make it extremely vulnerable to sudden changes in natural conditions and the weather, which have become quite common in this period.

Graph 2. Evolution of added value in agriculture sector $(2005=100 \%)$

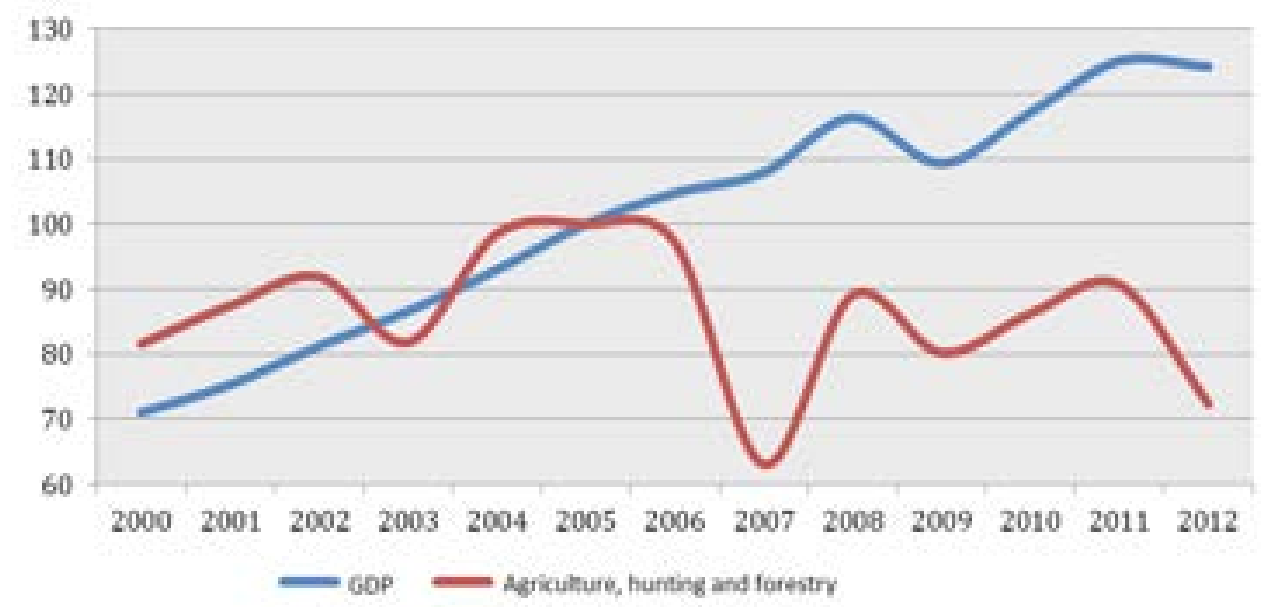

Source: According to the National Bureau of Statistics of the Republic of Moldova.

According to the World Bank data, in regional aspect, the Republic of Moldova is among the countries with the lowest level of labour productivity (Table 1). Quantified as the ratio of value added per worker, expressed in USD in 2005 prices, the labour productivity in the sector amounted to USD 1,884.3, much smaller than in the countries from the region, let alone the European average. 
Table 1. Labour Productivity in Agriculture

\begin{tabular}{|l|r|r|r|r|r|r|r|}
\hline \multicolumn{1}{|c|}{ Indicator } & EU & Romania & Turkey & $\begin{array}{c}\text { Republic of } \\
\text { Moldova }\end{array}$ & $\begin{array}{c}\text { Russian } \\
\text { Federation }\end{array}$ & Kazakhstan & Belarus \\
\hline $\begin{array}{l}\text { Labour } \\
\text { Productivity, } \\
\begin{array}{l}\text { USD } \\
(2005=100 \%)\end{array}\end{array}$ & $18,380.4$ & $8,067.8$ & $6,597.8$ & $1,884.3$ & $5,968.6$ & $3,532.5$ & $7,845.5$ \\
\hline
\end{tabular}

Source: according to World Bank data, 2012.

Low productivity can be explained by several reasons:

- farm structure, concentrated mainly in small households. According to 2012 data, about $50.8 \%$ of agricultural production was obtained in population households;

- weak farm endowment with technical equipment, the agricultural machinery owned by farmers being most often morally and physically obsolete;

- low level of education of the population employed in the sector, which adversely affects the structural transformation process and technological progress;

- poorly diversified structure of the sown areas, etc.

\section{Competitiveness of Moldovan foreign trade with agri-food products on the European Union market and the Customs Union market - Russian Federation, Kazakhstan and Belarus}

The agricultural sector is a separate branch in many economies, including those developed; some of the reasoning for this hypothesis has been mentioned above. In particular, in case of the latter, although agriculture is not necessarily the main branch ensuring economic growth, these countries are important players in the international market of agri-food products.

And the risk is much higher in countries, where the sector has a determinant role in its production and exports structure. Or in this case, the competitiveness of the sector, which indicator is both the internal and external performance represented a key factor in reducing its volatility to various changes in the market or natural conditions and the stability of the entire economy accordingly.

Here we can talk about the Republic of Moldova, a small country, with a high degree of openness, but characterized by a high level of dependence on imports. The sources ensuring the national income growth are less diversified and unsustainable over time.

The Republic of Moldova suffers from a chronic deficit of the current account. The small geographic area and the lack of special natural resources inevitably ensure a high dependence of the economy on imports, but for many years, along with the facilitation of foreign trade operations, the mass import of those products that the country would be able to produce with its own forces. At the same time, on the revenue side - revenues generated from exports are volatile revealing the specifics of the local production sector, 
where the agriculture and food industry have a relatively high share; the high share of re-exports, geographical concentration on high risk markets etc. The influx of foreign investment is very small. Foreign investments even if these imply also the increased level of indebtedness from the outside, are slow to come. Remittances which are an important source of household income are not sustainable over time and experience has shown that the correlation between them and the performance of the production sector in the country is very fragile.

In this context, since the Republic of Moldova is prepared to form a deep and comprehensive free trade area with the EU countries, the external competitiveness of the Moldovan agri-food sector was analysed with a view to assessing the potential impact of trade liberalization over this. Additionally, a comparative analysis with the countries of the Customs Union - Russian Federation, Belarus, and Kazakhstan was included in order to obtain a vision of the effects that could generate an alternative decision on joining this structure.

According to 2012 data, although it is not the most relevant indicator, given the high fluctuation of agricultural production due to drought in the respective year, the agri-food production valued about USD 875.3 million; representing 40\% of total exports (Graph 3.). The size of the share is impressive compared to other countries in the region, which may serve, including as an indicator of the country's international specialization in this sector.

Graph 3. Foreign trade with agri-food products in territorial profile

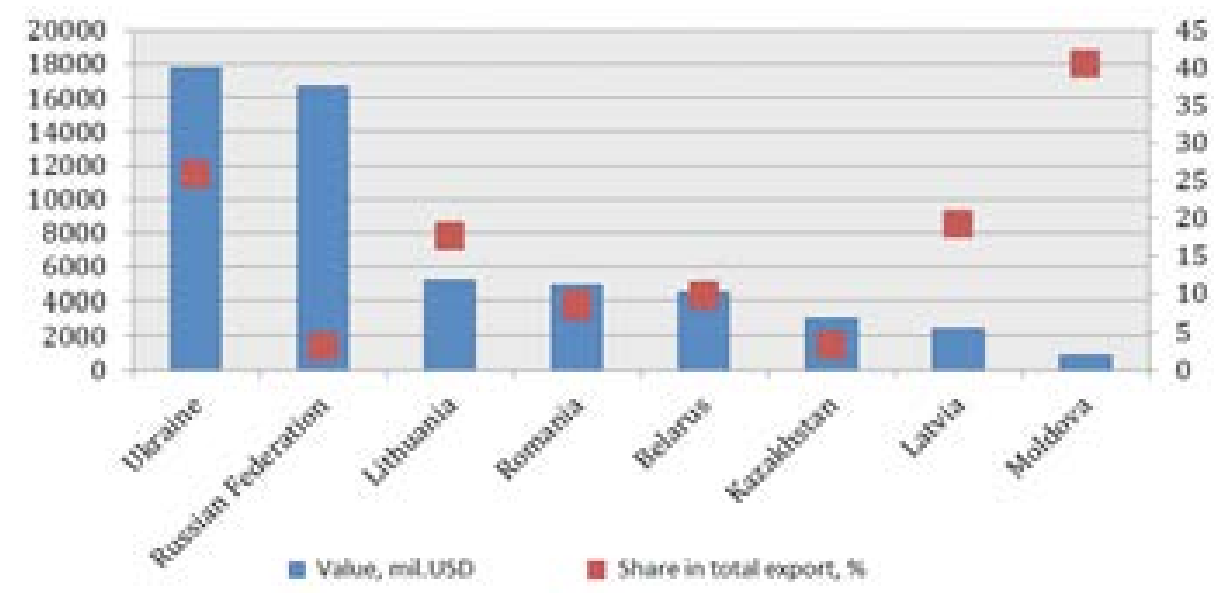

Source: According to the data of the National Bureau of Statistics of the Republic of Moldova.

The calculations made indicate a moderate level of concentration per product groups in this sector in the Republic of Moldova, Herfindahl Hirschman Index (HHI), calculated based on export data presented according to the Harmonized System Classifier (HS) disaggregated at 4-digit level, getting the value of 0.19 in 2012. The index calculated at a more disaggregated level indicates lower values, but which also fall within the limits of some moderate concentration indexes (Table 2). 
Table 2. Degree of export concentration by product category

\begin{tabular}{|c|c|c|c|c|}
\hline Indicator & 2009 & 2010 & 2011 & 2012 \\
\hline HHI (SA dez. 4) & 0,214 & 0,189 & 0,183 & 0,191 \\
\hline HHI (SA dez. 6) & 0,178 & 0,162 & 0,171 & 0,167 \\
\hline
\end{tabular}

Source: Author's calculations according to WITS data.

The main commodities contributing to increased exports of agri-food products are wine and grape must, wine distillate, shelled walnuts, sunflower seeds and sunflower oil, apples and apple juice, sugar, etc.

In fact, these goods are found mostly among the 10 main products exported by the Republic of Moldova for which also the world market share, though small, is higher compared to other products exported (Graph 4). In 2012, despite a reduction in agricultural production by $22.3 \%$ compared with 2011, Moldovan exports of agricultural products accounted for about $0.07 \%$ of world exports to this market. Meanwhile fruits have gained a market share of $0.21 \%$, alcohol beverages $0.2 \%$. It should be noted, however, that with the exception of wine, their production does not allow for the creation of a major added value or the agrifood sector is overall an area that has low capacity to increase the added value compared to other sectors.

Graph 4. Top 10 products in the Moldovan exports (in 2012)

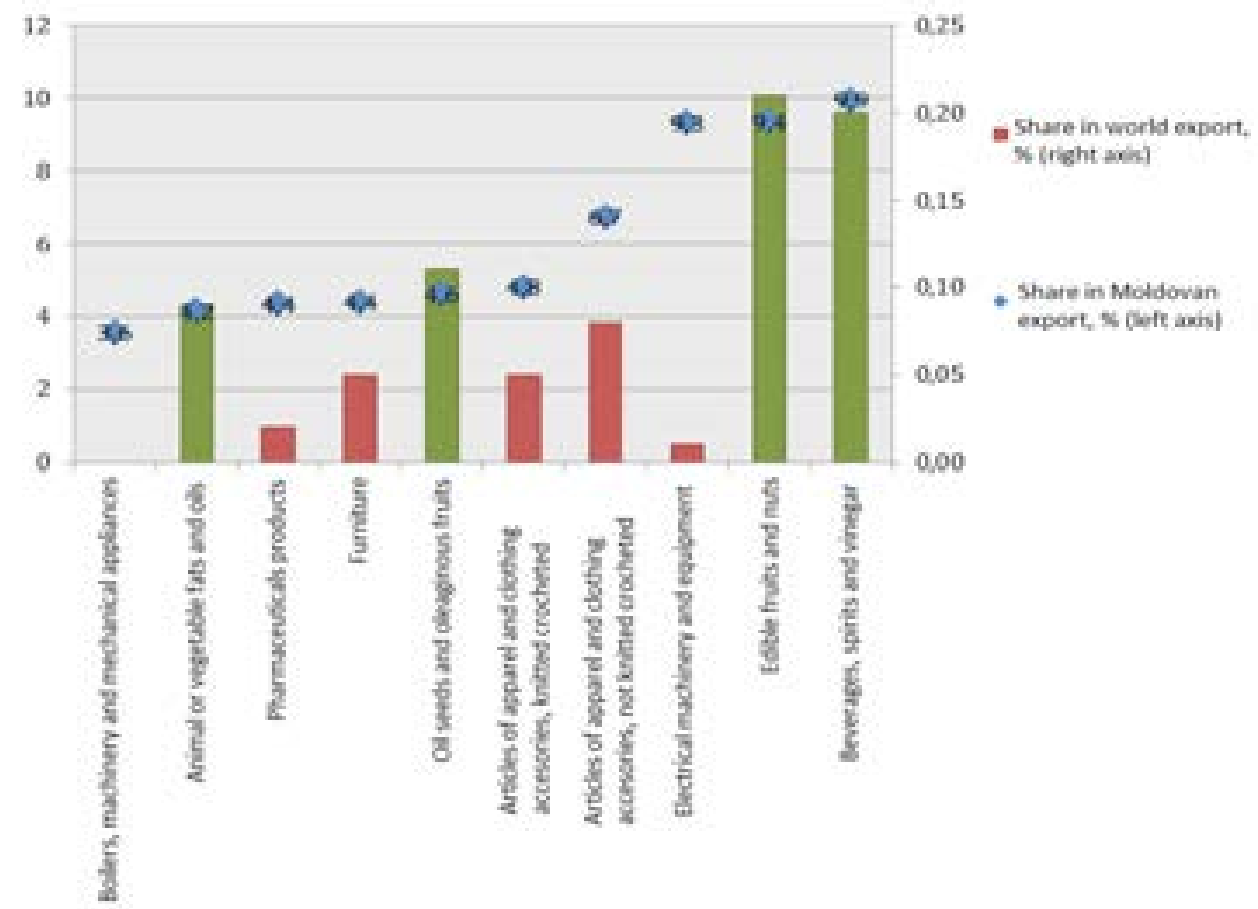

Source: According to the National Bureau of Statistics of the Republic of Moldova. 
The relatively high geographic concentration of agri-food products is a major constraint for the sector, which produced critical repercussions on this and its wine industry, in particular in 2006. In 2012, the geographic HHI was at the lower limit of transition from high to moderate concentration (Graph 5).

About $27 \%$ of exports of these categories of products are oriented towards Russian Federation. At the same time, the following nine main markets where three-quarters of Moldovan agrifood products are concentrated are as follows: Russian Federation, Romania, Belarus, Ukraine, Italy, Poland, Kazakhstan, France, USA and New Zealand.

In order to assess the competitiveness of agri-food exports to Western market and Customs Union trading partners in the Eastern area, the index on concentration and diversity of products exported from the point of view of the number of product categories exported in a disaggregated way at the level of 4 digits as per HS on both markets, including Turkey (Table 3) was calculated.

In $2012,78.4 \%$ of total exports of agri-food products, which corresponds to USD 688.9 million were exported to the Customs Union, European Union and Turkey. Separately, 37.9\% of exports of this product category were delivered to the Customs Union market, $38.6 \%$ to the EU and $1.8 \%$ to Turkey.

Graph 5. Geographical concentration of exports of agri-food products
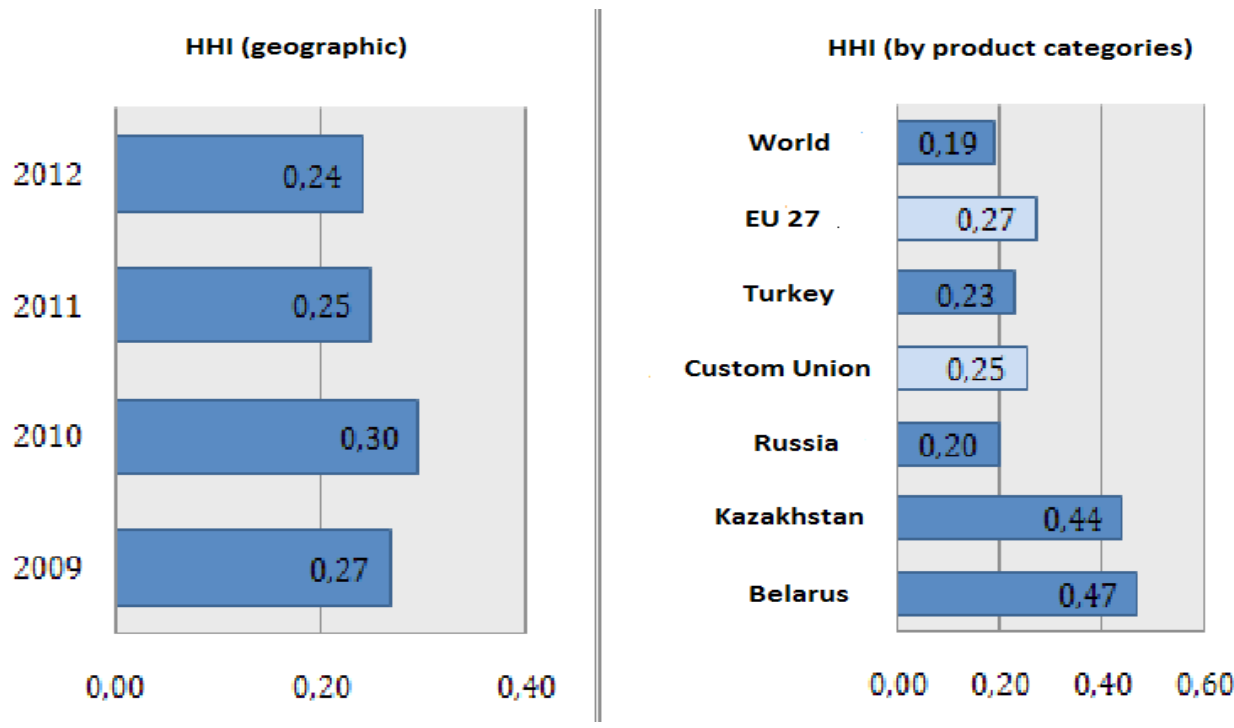

Source: Author's calculations according to WITS data.

First of all, it should be mentioned that the value of exports is distributed more or less equally between East and West. At the same time, in the Customs Union with three member countries, approximately $71 \%$ of the agri-food products are going to the Russian Federation, in the European Union, in 2012, half of the exports were delivered to the three main markets - Romania, Italy and Poland. 
Table 3. Number of products exported according to HS disaggregated at 4 digit level (in 2012)

\begin{tabular}{|l|r|r|r|r|r|r|r|}
\hline \multicolumn{1}{|c|}{ Indicator } & $\begin{array}{c}\text { Customs } \\
\text { Union }\end{array}$ & Belarus & Kazakhstan & Russia & Turkey & EU 27 & World \\
\hline Total number of products exported & 121 & 121 & 121 & 121 & 121 & 121 & 121 \\
\hline $\begin{array}{l}\text { Number of positions to } \\
\text { the respective destination }\end{array}$ & 71 & 37 & 36 & 62 & 15 & 76 & 121 \\
\hline
\end{tabular}

Source: Author's calculations according to WITS data.

Similarly, these markets, overall, show a high concentration by product groups. The Customs Union HHI in 2012 constituted 0.25, mainly due to the high concentration of exports to Belarus and Kazakhstan. In addition to this, the range of goods exported to these markets is very limited. According to HS disaggregated at 4 digit level, out of 121 categories registering exports in 2012, only about $30-31 \%$ of these were covered in Belarus and Kazakhstan.

Graph 6. Geographical distribution of exports of agri-food products (in 2012)

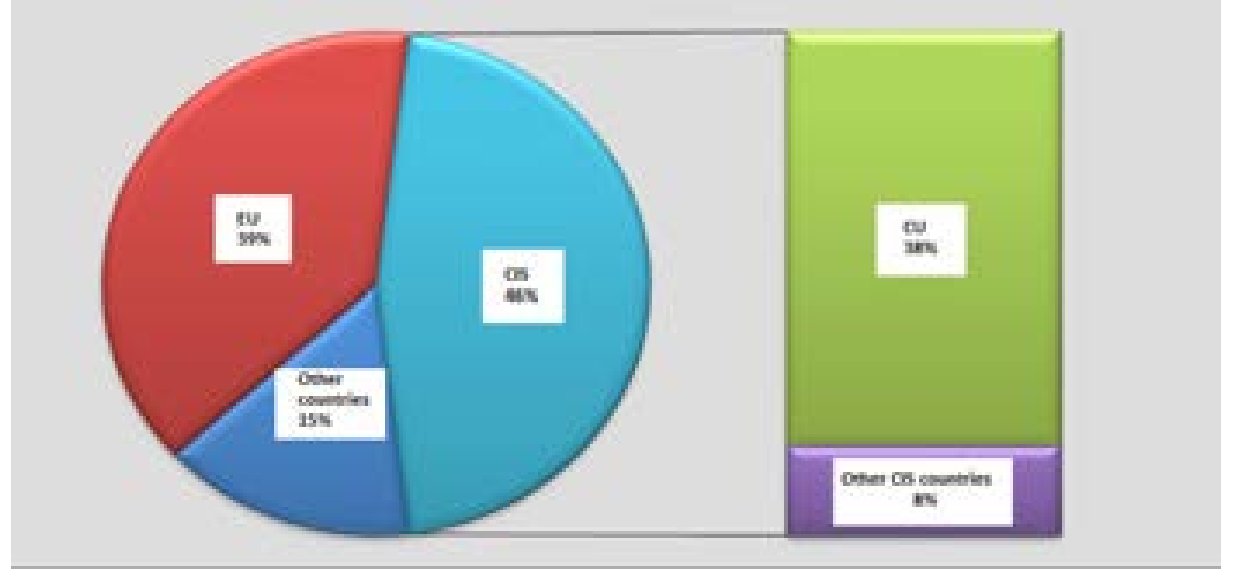

Source: Author's calculations according to WITS data.

Among the main categories of products exported to the Customs Union market are the following: grapes wine, apples, wine distillates, apricots, cherries and peaches, grapes, tomatoes, fresh or refrigerated beef, some of these being exported in the amount of $90 \%$ or even 100\% to that destination (Clipa, 2013). Around 66\% and accordingly, $61 \%$ of exports to Belarus and Kazakhstan was represented by wines and wine distillates.

The concentration degree of products exported to the European Union, indicate relatively higher values compared to the situation registered in the Customs Union. In 2012, about $43.5 \%$ of agri-food products exported to this market consisted of supplies of oil from sunflower seeds and nuts. At the same time, overall, the range of products exported to this destination is a bit more diversified compared to that directed towards the Eastern markets. Other products shipped to the European market in larger quantities are sunflower seeds, fruit juice, sugar made of cane or sugar beet and chemically pure sucrose in solid form, wine, soybeans and soybean oils, bakery, confectionery and biscuits even with cocoa, corn, etc. 
As for Turkey, while in 2013, it entered the top five major markets, the export of agri-food products indicates a degree of concentration that is placed between moderate and high, and their range was very narrow - 15 titles from HS classifier disaggregated at 4 digit level, represented, in fact, by the products exported in raw form. Among the top five exported agri-food products represented about $84.1 \%$ of the total were nuts, sunflower seeds, barley, rapeseed, wheat and meslin.

Based on those mentioned above, we can see that the top products exported to the $\mathrm{CU}$ and the EU, differ with some exceptions. With the exception of wine, which is among the top 10 main products exported both eastwards and westwards to the Customs Union predominantly agricultural products in fresh form are delivered: various fruits and vegetables, and meat, which is exported in very small quantities, or which import is even restricted in the European Union. On the other hand, both technical and cereal crops in a processed or raw form as well as other products of the food industry are exported to the EU. At the same time, it should be noted that the number of product categories for which the Republic of Moldova has a revealed comparative advantage (RCA) to export across the European Union and Turkey, 58 and 62 tariff categories is significantly lower than Customs Union - 86 tariff categories.

Table 4 shows the results of calculating the trade specialization index performed based on HS classifier disaggregated at 4 digit level using Bella Balassa's formula. The index is calculated by dividing a country's sectors share to total trade, on the one hand and the share of world exports in the corresponding sectors in the worldwide total exports, on the other hand (International Trade Centre).

This indicator is to be interpreted with caution, since it does not exclude the effect of various non-tariff barriers that could contribute to the creation of a comparative advantage in certain sectors, in this context, the most relevant example being the subsidies granted by various countries for this purpose. At the same time, it allows creating an overview of the industries where some countries have potential to compete on the international market.

According to the RCA index, the number of tariff headings for which the country has a revealed comparative advantage in worldwide trade is very limited - 17 out of 121 categories exported by the Republic of Moldova and 196 by the countries worldwide in 2012. At the same time, it is about those products for which the Moldovan exporters have a comparative advantage over all partners analysed.

Summarizing the main performance of agri-food products exports to these three destinations, several general trends could be outlined.

The Customs Union is the traditional market, enabling selling more than a third of Moldovan exports of agri-food products and the reduced imports from these destination permit to maintain a positive balance of trade, which value exceeded USD 200 million in 2010-2012. However, the bilateral trade with these countries has experienced a noticeable slowdown in recent years, the average annual growth in the period 2006-2012 placing it well below the overall average. Similarly, the high geographic concentration determines a high degree of volatility of exports to the Customs Union. 
Table 4. Products, in the trade of which the Republic of Moldova has a revealed positive comparative advantage worldwide and in relation to the partners from the Customs Union, European Union and Turkey (in 2012)

\begin{tabular}{|c|c|c|c|c|c|c|c|}
\hline$* * *$ & Worldwide & $\begin{array}{c}\text { Customs } \\
\text { Union }\end{array}$ & Belarus & Kazakhstan & $\begin{array}{c}\text { Russian } \\
\text { Federation }\end{array}$ & EU 27 & Turkey \\
\hline 1206 & 13,0 & 165,8 & 1747,0 & 212,9 & 148,2 & 82,7 & 50,7 \\
\hline 2307 & 5,6 & + & + & + & + & 45,3 & 201,1 \\
\hline 0802 & 5,2 & 1180,4 & 2197,6 & 1130,3 & 1142,9 & 129,0 & 5,7 \\
\hline 1512 & 4,6 & 14,5 & 385,7 & 85,8 & 11,8 & 68,9 & 13,6 \\
\hline 0809 & 3,6 & 2094,6 & 147,7 & 39983,2 & 215273,2 & 28,9 & 8,4 \\
\hline 2204 & 2,7 & 10101,5 & 1826,8 & 145838,1 & 13185,6 & 15,8 & 1081,6 \\
\hline 0808 & 2,7 & 291,2 & 20,8 & 23170,4 & 9602,9 & 24,8 & 60,0 \\
\hline 0205 & 1,7 & 766,9 & + & + & 606,9 & 14,1 & + \\
\hline 2001 & 1,7 & 78,2 & 7,2 & 1817,6 & 253,4 & 16,6 & 1,6 \\
\hline 2208 & 1,4 & 75,7 & 37,5 & 1834,5 & 70,2 & 8,4 & 161,5 \\
\hline 2009 & 1,4 & 210,5 & 222,1 & 1219,1 & 183,0 & 12,6 & 11,3 \\
\hline 2206 & 1,3 & 435,2 & 55,2 & + & 762,1 & 9,4 & 814,1 \\
\hline 2306 & 1,3 & 7,5 & 22,7 & 11,7 & 6,6 & 16,1 & 214,3 \\
\hline 1703 & 1,1 & 7,7 & 10,6 & 18,9 & 6,8 & 20,0 & 2818,2 \\
\hline 0806 & 1,1 & 1020,5 & 135,5 & 496,6 & 4232,9 & 16,6 & 1,5 \\
\hline 2105 & 1,0 & 30,1 & 9,9 & 582,9 & 30,5 & 5,4 & 9,4 \\
\hline 2005 & 1,0 & 71,2 & 30,4 & 1074,9 & 68,1 & 7,4 & 5,5 \\
\hline
\end{tabular}

Source: Author's calculations according to WITS data.

Note: Those positions for which the comparative advantage of the Republic of Moldova compared to the partners referred stems, mainly from the lack of exports of these countries as per these tariff headings were marked with "+".

Exports of agri-food products registered a relatively high dynamic during this period (Table 5). It is relevant that the Republic of Moldova exports to the Western countries also products with higher added value. At the same time, the exports remain highly concentrated; some products being even restricted on this market because of the failure of the domestic producers to comply with the European quality requirements. A pressure from imports that were also growing is felt; at the same time, the degree of coverage of imports by exports, being superior to the $100 \%$ level.

Table 5. Growth rate of the foreign trade of the Republic of Moldova, (annual average, 2006-2012), (in \%)

\begin{tabular}{|l|r|r|}
\hline \multicolumn{1}{|c|}{ Direction of trade flows } & \multicolumn{1}{|c|}{ Export } & \multicolumn{1}{c|}{ Import } \\
\hline MD total & 7,1 & 17,0 \\
\hline MD - UE & 18,8 & 15,6 \\
\hline MD - Turkey & 100,1 & 28,1 \\
\hline MD - UV & 2,7 & 11,7 \\
\hline
\end{tabular}

Source: Author's calculations according to WITS data. 
As for Turkey, the Republic of Moldova seems to be disadvantaged on the agri-food products market in the competition with this partner, attesting a negative trade deficit in the bilateral trade. The exports are relatively small, moderate concentration, but poorly diversified, consisting mostly of unprocessed agricultural products (Graph 7).

Graph 7. Evolution of trade balance deficit with agricultural products of the Republic of Moldova (in 2012)

$\square$ Customs Union $\quad \square$ European Union $\quad \square$ Turkey

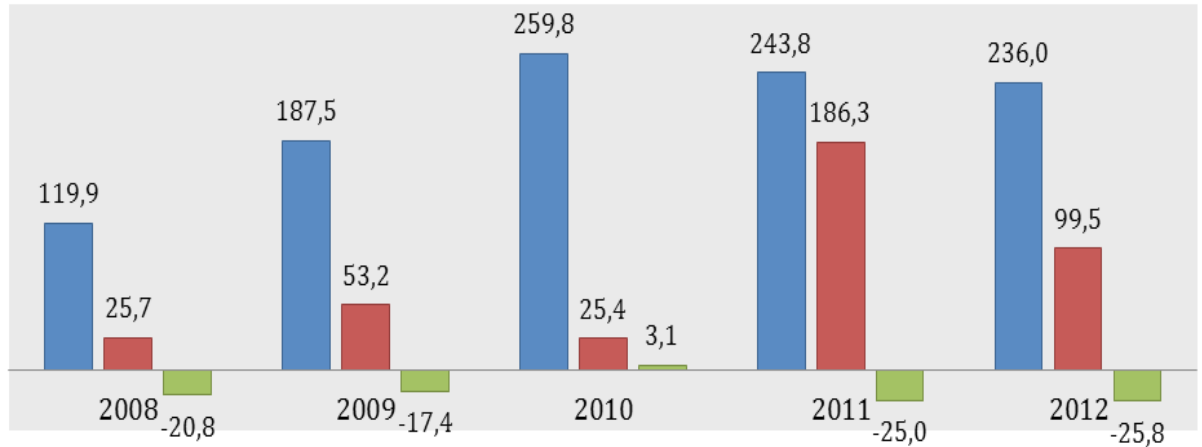

Source: Author's calculations according to WITS data.

Key indicators of development of the sector as a whole, indicates the existence of a set of main constraints over substantive limited domestic supply of agri-food products, along with other factors that reduce the competitive ability of local farmers. Here, the following could be mentioned: the underdeveloped quality infrastructure, underdeveloped agricultural infrastructure, excessive fragmentation of agricultural land, reduced business culture and lack of cooperation between producers and others.

\section{Balance of the risks and integration options opportunities of the Republic of Moldova for the agricultural sector}

In November last year, the Republic of Moldova initialled and then signed in June current year the Association Agreement with the European Union, which directly provides for the creation of a Deep and Comprehensive Free Trade Area (DCFTA) between the parties, and will try to continue the assessment of the main risks and opportunities for the local agri-food sector. Also in this context, the potential effects shall be appreciated that may bring a deeper economic integration in the CIS - joining the Customs Union - Russia, Belarus and Kazakhstan.

\section{Impact of the DCFTA with the European Union}

Currently, the foreign trade between the Republic of Moldova and the European Union takes place within the asymmetric preferential trade regime, meaning " 0 " tariff for agrifood products exported to these destination, with some exceptions: 
- products of animal origin, cereals, white sugar and grape wine that are allowed to be exported within the established tariff quotas;

- fruits and vegetables exempted of VAT payment at import. At the same time, many of these products are subject to a minimum price of entry at import (Council Regulation, 2008).

Several previous studies indicate that even in these conditions, the local exporters cannot fully benefit from the existing preferential regime. The biggest constraint in this regard is their low capacity to adjust to the European quality standards. Although for many years, the Republic of Moldova has started upgrading the quality infrastructure; this process is costly and time consuming.

Including due to this reason, the agri-food industry has been given a special role in negotiating the agreement, both regarding the import in the Republic of Moldova and in the EU. Thus, according to the Association Agreement, Title V - dedicated to the trade and trade-related areas and annexes aimed at this title, by signing this Agreement, the parties will grant each other free market access for products originating in the Republic of Moldova and the EU, with some exceptions.

The European Union will maintain certain tariff and non-tariff barriers for certain products:

- tariff rates - tomatoes, garlic, grapes, apples, plums, grape juice;

- customs duty without VAT - artichokes, cucumbers, zucchini, oranges, clementine, mandarins, pears, apricots, cherries, nectarines, peaches, grape, etc.

The Republic of Moldova will reserve the right to gradually liberalize the import of products according to some predefined schemes, in different terms, depending on the sensitivity of the sector. In this way, some instruments can be distinguished in this respect:

Reducing tariffs in three annual steps, starting from 1 January of the year following the entry into force of the Agreement - melted cheeses, other than grated or powdered like;

Reducing tariffs in 5 annual steps, starting from 1 January of the year following immediately after the entry into force of the Agreement - fresh cheese (including whey cheese) unfermented and curd, tomatoes, onions, zucchini, carrots, cucumbers, sweet peppers, nectarines, strawberries, effervescent wine and grape must, etc.;

Reduction of tariffs in 10 annual steps, starting from 1 January of the year following the entry into force of the Agreement - milk and milk cream, concentrated or with added sugar or other sweetening matter, cherries, canning and meat products, offal of turkeys, uncooked beef and others;

Reducing tariffs, starting from $1^{\text {st }}$ January of the fifth year after the entry into force of the Agreement - fresh, refrigerated or frozen eatable pork offal, grapes, apples, peaches, plums (Association Agreement between the European Union and the European Atomic Energy Community and their Member States, of the one part, and the Republic of Moldova, of the other part). 
In addition to these particular issues, based on this Agreement, "Parties shall commit themselves to enhance the cooperation and good neighbourly relations, including cooperation in the development of projects of mutual interest, in particular those aimed at preventing and combating corruption and criminal activities. These commitments are a key factor in the development of relations and cooperation between the Parties and contribute to the regional stability and peace.

In fact, this agreement represents a complex reform agenda for the Republic of Moldova in key areas to ensure the functioning of the economy according to the principles of market economy. The document will compel the local authorities to promote the necessary reforms in several areas: justice, public administration, competition, consumer protection, statistics, public finance management, industrial policy, corporate governance, energy infrastructure, transportation, quality, social policy, etc.

If these reforms are not be promoted by the public authorities, business environment and society as a whole, the agreement could have a profound negative impact on the agri-food sector, which will produce chain effects on other areas - employment, standards of living of the population, public finance, etc.

Liberalization of imports of agri-food products in the European Union and Turkey would mean the elimination of import customs tariffs, which would correspond to a reduction in the price of imported goods by about $10 \%$ within maximum 10 years. According to the WTO data, in 2012, the simple average of MFN tariff in the Republic of Moldova for this product category was of $10.5 \%$. Based on separate categories, the simple average tariff was of: $14.7 \%$ for animal products, $12.8 \%$ - fruits and vegetables, $10.2 \%$ - cereals and cereal products, 13 $\%$ - beverages and tobacco. In particular for wines, for one litter of imported wine, a duty of 0.5 euro is levied etc.

Although competitive pressure will bring benefits to the local consumers, this might also influence their income levels, given the high level of employment of the population in agriculture. Removal of any protection tools for this sector without increasing its immunity could cause higher unemployment and relatively low qualifications and reduced training of the workers could create problems in their reorientation towards other sectors.

At the same time, the correct and responsible promotion of the reform program could generate multiple opportunities for the sector:

- creating an equitable business environment and a functioning market with fair competition rules;

- increased foreign investment in the sector and its modernization;

- reducing the technical barriers and diversification of the range of products exported to this market;

- increasing export activity of the local entrepreneurs, enhanced by a regulatory framework of the long-term predictable trade relations; 
- development of the entrepreneurial culture following the intensification of trade relations with economic partners at a more advanced stage of development.

\section{Impact of a potential membership in the Customs Union}

As an alternative to creating a DCFTA with the European Union, we considered appropriate the assessment of the effects that could be generated by the accession of the Republic of Moldova to the Customs Union - Russia, Kazakhstan, and Belarus. Or even now, this issue is one that causes many discussions.

The trade regime with the current members of the Customs Union enjoyed a preferential treatment within the CIS, even since the country's independence. Since 2013, the trade relations with these countries are conducted within the multilateral agreement on the creation of a Free Trade Zone in the CIS, which was signed in 2011.

This agreement replaced the multitude of bilateral free trade agreements between the countries, establishing a single regulatory trade framework for all Member States. This ensures, to a great extent, the elimination of any kind of mutual trade barriers, although even within this, some tariff barriers have been preserved, the most relevant in this respect being the export customs duties.

Unlike the commercial relations with the Western partners, the preferential trade regime with the member countries of the Customs Union is symmetrical, which implies free access to mutual markets.

In this context, according to the existing empirical evidence, it is unlikely that the adherence of the Republic of Moldova to this structure could create new trade flows in the mutual trade - a term defined in the literature as trade creation effect.

Indeed, the Republic of Moldova has a relatively higher specialization in the agricultural sector compared to the Eastern partners than the Western partners, but those advantages that could be provided by a preferential trade regime for enhancing the bilateral trade flows most likely have been used by now.

Table 6. Comparative aspects on MFN tariff rate in the regional profile (in \%)

\begin{tabular}{|c|c|c|c|}
\hline Country & All products & $\begin{array}{l}\text { Agri-industrial } \\
\text { products }\end{array}$ & $\begin{array}{l}\text { Industrial, non-agricultural } \\
\text { products }\end{array}$ \\
\hline Republic of Moldova & $4,6 \%$ & $10,5 \%$ & $3,7 \%$ \\
\hline Belarus & $9,7 \%$ & $13,4 \%$ & $9,1 \%$ \\
\hline Kazakhstan & $9,5 \%$ & $13,4 \%$ & $8,8 \%$ \\
\hline Russian Federation & $10,0 \%$ & $13,3 \%$ & $9,4 \%$ \\
\hline European Union & $5,5 \%$ & $13,2 \%$ & $4,2 \%$ \\
\hline
\end{tabular}

Source: According to World Trade Organization data.

About $38 \%$ of agri-food products traded outside the Republic of Moldova is exported to the Customs Union market. This is an exclusive market for the sale of some plant and meat products. And joining the Customs Union involving immediate abolition of controls at the internal borders, could contribute to the facilitation of trade in these product categories. 
Similarly, elimination of export duties of the member countries for various fuels, especially for the Russian natural gas, could reduce the costs for farmers.

However, if the Republic of Moldova accedes to the Customs Union, certain costs that would result from this process should be taken into account.

First of all, considering that joining the Customs Union would mean a common customs tariff and trade regime, the CU membership is incompatible with DCFTA, which the Republic of Moldova intends to sign with the European Union. Similarly, it could most likely have the effect of non-renewal of autonomous trade preferences granted by this, which would significantly affect exports of agricultural products on the western market. In this way, if currently, with certain exceptions, within the autonomous trade preferences, the exports of agri-food products enjoy free access to the EU market, then the cancelation of the trade preferences would mean imposing on Moldovan products entering the EU market an average tariff of about $13.2 \%$ (Table 6 ).

Exports of agri-food products in UV reflect a high degree of geographical concentration, this increasing the volatility of exports, and sector activity to various external shocks. And as shown by the experience of 2006, such shocks can sometimes have fatal consequences on some sub-sectors of agriculture and food industry.

The reduction of productivity in the sector, as a result of the increase in customs tariffs for industrial products, including capital imported from the third countries, so necessary for the technical endowment of the branch. It's about weak entrepreneurial culture and production organization as well as technical endowment of agricultural enterprises and farms that are reflected in the low productivity obtained.

Risk of delaying the promotion of some reforms necessary for the business development in general.

\section{Conclusions}

The dilemma between East and West for the Republic of Moldova is a topic that has seen many debates in recent years. Currently, the Republic of Moldova is on the eve of signing a Deep and Comprehensive Free Trade Agreement with the European Union that will put on an equal footing two important economic partners, being able to exploit the opportunities offered by the preferential trade arrangements and close cooperation with both.

At the same time, we have addressed this issue in the context of agri-food sector development prospects, considering it as still being an important one, or neglecting it could have adverse effects on the branch if the potential risks are not acknowledged.

Agriculture is one of the sectors that still provide a major contribution to ensuring the growth of the national economy. At the same time, in recent years, its evolution indicates a relatively high volatility, which also causes large oscillations in economic growth rates. 
For this reason, but also due to the importance of this sector to ensure development of rural areas and the country's food security, the agricultural development must have a special place in the economic policy of the state.

Regeneration of the sector and increase in its competitiveness abroad requires some radical measures that would produce changes in its structure. The signing of the Association Agreement with the EU could serve as instrument to stimulate this process, but the DCFTA establishment will present some challenges for the sector, which are to be properly addressed, for this not to turn into risks.

\section{Literature}

1. Aksoy, M.A., Beghin, J.C. (2005) Global agricultural trade and developing countries, The International Bank for Reconstruction and Development / The World Bank, 327 p.

2. Antevski, M., Petrović, P., Vesić, D. (2012) Development perspectives in agriculture and rural areas in Serbia in the EU integration process, Economics of agriculture, Belgrade, Vol. LIX, Nr.2 (177-356), pp. 243-250.

3. Association Agreement between the European Union and the European Atomic Energy Community and their Member States, of the one part, and the Republic of Moldova, of the other part, available at: http://eeas.europa.eu/moldova/assoagreement/ assoagreement-2013 en.htm

4. Chauffour, J. P., Maur, J. C. (2011):Preferential Trade Agreement Policies for Development, Washington: 2011, p. 111-112.

5. Chistruga, M., Clipa, V., Fala, A. (2010): Analiza performantelor exporturilor Republicii Moldova prin prisma regimurilor preferentiale de comert, Chisinau: Institutul de Economie Finante si Statistica (Analysis of the Republic of Moldova's export performance from the perspective of trade preferential regimes).

6. Clipa, V. (2013): Republic of Moldova: challenges and prospects on the accession to the Customs Union: Russia - Kazakhstan - Belarus vs. concluding the Deep and Comprehensive Free Trade Agreement with the European Union. INCE, 2013, available at: http://iefs.md/ro/activitatea-ince/publicacii/356-republic-of-moldova-challengesand-prospects-on-the-accession-to-the-customs-union-russia-kazakhstan-belarus-vsconcluding-the-deep-and-comprehensive-free-trade-agreement-with-the-europeanunion.html

7. Council Regulation (EC) No. 55/2008 of $21^{\text {st }}$ January 2008 introducing autonomous trade preferences for the Republic of Moldova and amending Regulation (EC) No. 980/2005 and Commission Decision 2005/924/EC.

8. Grant, J.H., Boys, K.A. (2012) Agricultural Trade and the GATT/WTO: Does Membership Make a Difference?, American J. of Agricultural Economics, Vol. 94, Issue 1, pp. 1-24.

9. International Trade Centre, Trade competitiveness map available at: http://legacy. intracen.org/appli1/TradeCom/Documents/TradeCompMap-Trade\%20PerformanceHS- 


\section{UserGuide-EN.pdf}

10.Lambert, D., McKoy, S. (2009) Trade Creation and Diversion Effects of Preferential Trade Associations on Agricultural and Food Trade, Journal of Agricultural Economics, Vol. 60, Issue 1, pp.17-39.

11. Sarker, R., Jayasinghe, S. (2007) Regional trade agreements and trade in agrifood products: evidence for the European Union from gravity modeling using disaggregated data, Agricultural Economics, Vol. 37, Issue 1, pp. 93-104.

12. Stratan, A., Moroz, V., Lucasenco, E. (2012): Diagnosis of the agri-food value chains in the Republic of Moldova. Proceedings, International Symposium on Agrarian Economy, p. 302 .

Websites:

13. World Bank, available at: http://wits.worldbank.org/CountryProfile/Country/MDA/ Year/2012/Summary http://wits.worldbank.org/CountryProfile/Country/MDA/

Year/2012/TradeFlow/Export/ http://wits.worldbank.org/CountryProfile/Country/MDA/ Year/2012/TradeFlow/Export/show/Exports $\% 20$ Share $\% 20 \% 28 \% 60 \% 29 ;$ Trade $\% 20$ Value \%20\%28US\$\%20Thousand\%29;Nbr\%20Of\%20Traded $\% 20 H S 6 \% 20$ digit $\% 20$ Products/Sort/Trade\%20Value\%20\%28US\$\%20Thousand\%29 http://wits.worldbank. org/CountryProfile/Country/MDA/StartYear/2008/EndYear/2012/TradeFlow/Export/ Indicator/Trade\%20Value\%20\%28US\$\%20Thousand\%29/Partner/All/Product/WTOSoP1\# http://wits.worldbank.org/CountryProfile/Country/MDA/Year/2012/TradeFlow/ Import/Partner/WLD/Product/All\%20Groups http:/wits.worldbank.org/CountryProfile/ Country/MDA/Year/2012/show/Development\%20Indiator\%20-\%20GDP,\%20GNI\%20 and $\% 20$ Others http://data.worldbank.org/indicator/EA.PRD.AGRI.KD

14. UNCTADstat, available at: http://unctadstat.unctad.org/wds/TableViewer/tableView. aspx

15. National Bureau of Statistics of the Republic of Moldova, available at: www. statistica.md/pageview.php? $=$ ro\&idc $=315 \& \mathrm{id}=2278$ www.statistica.md/category.php?1=ro\&idc $=336 \&$

16. World Trade Organization, available at: www.wto.org/english/res_e/reser_e/tariff_ profiles_e.htm 